\title{
Peter Gathercole (1929-2010): A Life Well-Lived
}

\author{
Matthew Spriggs, The Australian National University, Canberra, \\ Australia \\ E-mail: Matthew.Spriggs@anu.edu.au
}

Peter Gathercole, museum anthropologist, teacher, archaeologist, biographer of V.G. Childe and long-time supporter of the aims of WAC, died on 11 October in Kernow/Cornwall, UK. The funeral was held on 5 November in Cambridge, where his partner Bobbie Wells lives.

A lifelong Marxist, it was Peter's undergraduate involvement with the Communist Party that brought him into early contact in 1949 with past WAC President, Jack Golson, at Cambridge University. They remained firm friends until Peter's death, both leaving the Communist Party in the 1950 s as the contradictions of Stalinism became ever-clearer. It was Jack who encouraged Peter to switch to Archaeology from History for his first degree (awarded 1952). Peter had come to University after his military service in Egypt in the Royal Army Education Corps, while Jack had resumed his studies after conscription as a 'Bevin Boy' in the Nottinghamshire coalfields. Peter took out a Postgraduate Diploma at the Institute of Archaeology in 1954, studying under Vere Gordon Childe. It was Jack Golson again who encouraged Peter a few years later in 1958 to make the move to New Zealand to take up the second academic appointment created in archaeology in that country. Jack, in Auckland on the North Island in 1954, was of course the first such appointment. Peter quickly established the University of Otago in Dunedin on the South Island as the second great centre of archaeological teaching and research. The friendly rivalry between these two key New Zealand departments of anthropology continues to this day.

Peter had started his post-degree professional career working at the Birmingham Museum and Art Gallery from 1954 to 1956, and before heading overseas had been the Curator of the Scunthorpe Museum and Art Gallery from 1956 to 1958. After his New Zealand interlude ended in 1968 he again took up his museums career at the Pitt Rivers Museum in Oxford, moving to Cambridge in 1970 as Curator of the University Museum of Archaeology and Ethnology. During the rest of his career he produced numerous publications in the field of museum anthropology, often returning to consideration of Pacific and of course particularly New Zealand Maori artefacts and their meanings. 
After his retirement from the Museum in Cambridge, another career change occurred as Peter became Deputy-Dean and then Dean of Students of Darwin College, Cambridge from 1981 to 1987. Darwin is a graduate college with a large proportion of overseas students, and Peter's job was the admission and pastoral care of all 300 of the student body. This was really his métier and he was brilliant at it. I often meet former students who remember him extremely fondly from that period of his life.

He retired from his Darwin Fellowship in 1996, moving down to Cornwall, a place he had loved since being evacuated there as a St. Paul's Cathedral chorister near the beginning of the Second World War. But there is retirement and then there is retirement! Peter flung himself into active involvement in the Cornwall Archaeological Society, its Journal long behind schedule and struggling. From 1997 to 2000 he was President of the Society and Editor of its Journal, continuing this latter duty until 2003. In 2004 he was made Honorary Vice-President of the Society, having at great personal effort got publication of its journal back on track.

Peter's archaeological and museum publications span from 1955 until his death left some papers still at the press. During this 55-year span he produced several jointly-written or -edited books, over 30 contributions to edited volumes, over 30 refereed journal articles and over 50 other articles, reports and exhibition catalogues. He was a thoughtful and fair reviewer of books, beginning with his review of J.S Weiner's The Piltdown Forgery in the Daily Worker for 17 February 1955. During his career about 100 reviews appeared under his name in various journals, particularly in Antiquity and Pacific Arts, and in the Times Literary Supplement. As well as Pacific material culture, he was the most penetrating of Childe's biographers. Although the long-promised synthesis of the great man's intellectual history never eventuated, the series of papers by Peter on the topic from 1971 onwards are in many ways 'the last word' on Childe.

In 1985-1986 Peter was a Visiting Lecturer at Southampton University, teaching Peter Ucko's courses while the latter concentrated on organising what became the 1986 World Archaeological Congress. In his contentious 1987 book, Academic Freedom and Apartheid, Ucko talks of Peter as "both a source of comfort and of erudite understanding and stimulating suggestions" (p. 113), and at one particular turning point in discussions with the then parent organization, the IUPPS, notes that Peter had "sustained me so often during the previous months" (p. 121). Sadly, Peter's all-toounderstandable second thoughts about the way the Congress was shaping up in relation to the ban on South African participation and other substantive issues, was seen as some sort of betrayal (see pp. 150-151) — which of course it wasn't. Be that as it may, the session Peter co-organized with David Lowenthal on 'Politics of the Past' was certainly to the point and was one of the most interesting sessions at the 1986 Congress. A book of 
the same title, edited by the convenors, was published as part of the One World Archaeology Series in 1990 (paperback edition in 1994).

Peter Gathercole's particular understanding of Marxism informed his practice and his deep humanistic spirit. He was someone of whom one could say without reservation that he was a truly decent person. He had a slightly archaic kind of politeness, was a very good listener and he cared deeply about the welfare of others, sometimes to the detriment of his own.

Peter will be mourned by friends on all continents and in many walks of life. As well as his partner Bobbie, he is survived by his previous wives Falmai and Adrienne, and the four children of his first marriage. The funeral was an understated affair on a wet, cold and windy Cambridge November day. I felt honoured to be able to attend as a friend and former undergraduate student-it is through Peter that I started my own career in the Pacific — and as representing his many Pacific and Australasian friends. 